\title{
URBAN DEPRAVITY, RURAL UNSOPHISTICATION: HEREDITARY TAINT IN HARDY'S TESS OF THE D'URBERVILLES
}

\author{
By Rosanna Nunan
}

CRITICS HAVE USED VARIOUS APPROACHES to explain the paradoxes or inconsistencies evident in the characterization of Angel Clare in Thomas Hardy's Tess of the D'Urbervilles (1891); however, by examining the social purity movement and its response to increasingly popular theories of degeneration at the fin de siècle, we can understand the interplay of contradictory ideas at work in Angel. ${ }^{1}$ The tension between the supposedly modern, secular viewpoints that Angel exhibits in the beginning of the narrative and his unexpected return to a conservative and misogynistic ideology upon Tess's confession of her "fall" puzzles readers, fellow characters, and perhaps even the narrator of the novel itself, who accounts for the alteration as simply the hypocrisy of a man who "was yet the slave to custom and conventionality when surprised back into his early teachings" (Hardy 265; vol. 2, ch. 39). ${ }^{2}$ Oliver Lovesey suggests that the reason why "Clare somewhat bombastically renounces his father's Christianity, but ... still stumbles on elements of traditional social morality" and why he "bypasses the resurrection, but cannot negotiate around Tess's 'unintact state" "is that Tess's "virginity replaces the resurrection in his religion of unbelief" (913-14). Lovesey argues that Angel displaces religious faith in Christ's resurrection onto a material substitute, Tess's virginity, and that the revelation of her lack of virginity then catapults him into a despair akin to the despair of annihilated spiritual belief, "the void of an unbeliever's hell" (924). While I am also concerned with Angel's fetishization of virginity, I believe that it is significant that his obsession with purity extends beyond Tess's virginity to encompass rural space as a whole, a space in which Tess's virginity constitutes but one part. The very capaciousness of Angel's devotion to purity situates him squarely within the environmental binaries characteristic of later theories of urban degeneration.

Through Angel, Hardy formulates a critique of determinist and degenerative ideologies by focusing on Angel's displacement of fin de siècle fears of urban decay onto Tess's individual body. Though critics have commented extensively on Angel's objectification of Tess, the manner in which this objectification fits within a larger problem of environmental and hereditary determinism has yet to be accounted for in terms of Angel's complex attempt to inhabit a world ruled by fears of urban degeneration. ${ }^{3}$ Other Victorian texts commenting upon degeneration and the city in this era typically debate the legitimacy of degenerationist accounts of urban dwellers. ${ }^{4}$ Hardy instead develops a narrative centered upon a degenerationist's approach to the countryside and a country dweller to reveal the consequences of a 
conception of degeneracy increasingly biologized and distanced from its original ties to environment. ${ }^{5}$

Hardy critically examines the displacement of environmental concerns onto the bodies of individuals within degenerationist discourse. He represents Angel Clare's conflation of an idealized rural environment with Tess's rural body as a result of his fears of degeneration. Angel requires consistency between Tess's body and environment; her body needs to be pure, healthy, and free from the sexual contamination that stands for a variety of what Victorians categorized as hereditary urban illnesses, both physical and moral. When faced with the knowledge that Tess is not a virgin, Angel considers this not only as symbolic of Tess's physical and moral depravity, but also as proof of her inconsistency with the rural. Angel blames what he understands to be her depravity on the hereditary influence of the aristocratic D'Urbervilles, whom he associates with both aristocratic and urban degeneracy. Hardy's representation of Angel as a follower of the social purity movement situates his rejection of Tess within fin de siècle fears of urban degeneracy and the increasing pathologization of urban individuals through arguments of hereditary transmission of vice. Though a country dweller, Tess's descent from the medieval D'Urbervilles enables Angel to justify her apparent sexual depravity through competing but intersecting accounts of aristocratic and urban degeneration. Hardy highlights Angel's extreme interpretation of theories of urban degeneracy in order to reveal the consequences of a discourse that burdens the bodies of oppressed individuals with the ills born of poor social and economic conditions.

\section{Degeneration, the City, and Social Purity at the Fin de Siècle}

SPECIFIC CIRCUMSTANCES IN LATE nineteenth-century culture inform Hardy's response to society in the novel, and the best place to look for such a local treatment of social problems is in Angel, whom Hardy describes in later editions of the novel as "a sample product of the last five-and-twenty years." ${ }^{\prime}$ While Lovesey's discussion of the religious quandary in Angel's nature provides us with a possible framework with which to understand this perplexing character, I propose that we can further elucidate Angel's rejection of Tess when he realizes that she is not a virgin, and thus must be a fallen or unvirtuous woman, by examining it in the context of the medically motivated "social purity movement" of the 1880 s and 1890s. ${ }^{7}$ As others have demonstrated, social purity activists diverged from their progressive women's rights agenda in the era before the repeal of the Contagious Diseases Acts in 1885 and became increasingly conservative adherents of degenerative theories, eventually committing to eugenics as their movement's main platform. ${ }^{8}$ Referring to determinist theories of degeneration in late nineteenth-century works of the naturalist genre, Angelique Richardson explains a popular social purity novelist's difference from the naturalist writers of the same period. She writes, "In striking contrast to the naturalists, who had no aim, or belief in the past or future, [Sarah] Grand's aim was future certainty, through the application of knowledge gained through close reading and interpretation of the past" (Love 127). Social purity activists set themselves in sharp distinction to the positivist materialists of the era, such as naturalist writer Emile Zola. Unlike positivist materialists, social purists retained an interest in assuring "future certainty" through the identification and perpetuation of favorable hereditary traits determined by the examination of individuals' ancestral history, ultimately seizing upon eugenics as the only way to save society from degeneration. Angel, like late nineteenth-century social purity activists, attempts to resolve the all-encompassing 
destruction forwarded by degenerative theories by positing the existence of diseased and healthy spaces. ${ }^{9}$ Angel possesses "an almost unreasonable . . . aversion to modern town life" because he subscribes to these tenets of social purity (116; vol. 1, ch. 18). Hardy emphasizes that Angel's belief that the countryside is a pastoral ideal of healthiness and purity is an imaginative construct built upon Angel's exposure to classical pastoral poetry and other myths; however, Angel's approach to the country and his fear of the city also illustrate the damaging effects of a conception of tainted urban environments that Victorians easily displaced onto individual bodies with the rising influence of hereditarian explanations for disease and mass poverty.

Because of their movement's association with the problem of prostitution and the spread of venereal disease, the social purity activists believed that their biggest responsibilities lay with the city. They saw high rates of prostitution and engagement in illegal or unadvisable sexual activity as afflictions of city life and modernity particularly. ${ }^{10}$ Lesley Hall writes that "social purity and sex reform" in the last decades of the nineteenth century "had common roots as responses to the phenomena of urbanization and modernization" (37). Danielle R. Egan and Gail Hawkes similarly explain that "modernization and the breaking down of traditional norms and mechanisms of social control signaled a significant societal turning point for purity reformers" and that "urbanization offered a unique condition for reform" (449). The purity activists' selection of the city as the focal point of their sexual reform agenda was motivated not only by high rates of prostitution, but also by the increasingly popular concept of urban degeneration. Moral reform was intimately tied to escalating fears of degeneration in London because Victorians viewed the problem of prostitution and the spread of disease (especially syphilis - categorized as hereditary - the physical manifestation of moral depravity that could be passed on to children ${ }^{11}$ ) as further evidence that slum conditions in London resulted from the growing biological inferiority of its inhabitants rather than a broken economic or political system. $^{12}$

As a consequence of the pathologization of the city, social purity activists idealized the healthiness of the countryside. In Outcast London, Gareth Stedman Jones explains that late nineteenth-century social scientific studies on the condition of London display a common "belief in the innate superiority of the country immigrant over the London born" and further notes that social scientist "Llewellyn Smith connected the demoralization of the East End with the comparatively low proportion of provincial immigrants to the district" $(129,130)$. As in the texts Stedman Jones examines, in Tess Hardy alludes to a conception of innate urban weakness when Angel tells Tess that the milk that urban dwellers receive from the country needs to be watered down before they can drink it. Londoners will drink the milk, though Angel qualifies, "not as we send it. When its strength has been lowered, so that it may not get up into their heads" (187; vol. 2, ch. 30). Angel's quip situates the novel in a context of urban overpopulation and degeneration. Writing of the 1880s, Megumi Kato explains that "in late Victorian Britain, the redistribution of the population to cities created a demand for milk far removed from its source. In the intervening period from farmers to consumers, milk was subject to contamination and infection" (5). The contamination of milk between country and city gave rise to essays like "Milk and National Degeneration" and "Discussion on the Control of the Milk Supply" at the turn of the century (Childs 34). Although Angel does not explicitly connect milk with the ideas of contamination or degeneration, his insinuation that urban dwellers, unlike hardy rural inhabitants, are not strong enough to handle country milk, connotes the same conception of urban weakness and decay that Stedman Jones reveals 
to be prevalent in the social scientific texts at the time. Nothing disgusts Angel more than the possibility that, despite her rural appearance, Tess may be "a coquette of the first urban water," precisely because he associates urban dwellers with physical and moral depravity in the same manner that Stedman Jones describes (Hardy 177; vol. 2, ch. 28).

Optimists at the fin de siècle hoped that integrating rural inhabitants into urban environments would strengthen the latter, though most Victorians, including Angel in Tess, were unconvinced by this supposition. Richardson describes the development of a "Garden City Movement" at the turn of the twentieth century, which, influenced by the rural utopian imaginings of William Morris in News From Nowhere, envisioned "improving the conditions of working-class lives through the marriage of town and country" (Love 134). On the one hand, social purity activists entertained the idea that integration of country elements into the city, either through immigration of rural laborers or the redesign of urban spaces into a "garden city," would have the effect of mitigating urban degeneration. On the other hand, many believed that quarantining working class urban spaces was the only solution to the spread and self-perpetuation of degeneration. Stedman Jones claims that "the absence of a proper historical explanation" for urban poverty "drove [social scientists] to mythological conclusions" based on the traditional opposition of country and city (138).

Theorists emphasized the risk of contamination should degenerate urban dwellers and healthy country dwellers come into too close contact with each other. The Victorian middle class, using the hypothesis of rural superiority, concluded that "the long-run consequences of the [rural] migration into the towns would be a progressive deterioration of the race" because hardy rural dwellers would be tainted by urban contact (Stedman Jones 286). ${ }^{13}$ Richardson writes that "the theory of degeneration underpinning analyses of the urban poor came increasingly to focus on the division between country and city, bringing environmental and biological concerns together in the name of regeneration" (Love 132). The fear of contamination of the as yet healthy countryside through urban contact created a desire for the containment of the bodies of poor urban dwellers. Daniel Pick discusses the increased responsibility individual bodies shouldered within discourses of degeneration as a result of the conceptual relocation of the source of disease from unhealthy environments to the persons who inhabited these environments. He writes, "What we begin to see is an insistent crossreferencing of social preoccupations about the city with the specifically physical description of an impoverished nervous system and circulation" (191). He further explains:

It is the degenerate rather than degeneration which was most deeply opposed. The notion of society as an organism . . . becomes an increasingly "dead metaphor," in other words a metaphor used literally, in the social criticism of the late-Victorian period. . . The body itself was symbolized in new ways, its dramatized image standing as a figure of society. (180)

Richardson similarly writes that the fin de siècle witnessed "a new emphasis in fiction on the link between sexuality and disease, and a new focus on the body as a marker of health" (Love 122). As Pick's comment about the "dead metaphor" of the social organism makes clear, the fin de siècle's pathologization of urban dwellers was not the same as the conceptualization of a metaphorical "body politic," in which the condition of society is represented through an abstracted diagram of the human body, familiar from history. ${ }^{14}$ Instead, the bodies of urban dwellers themselves were diseased; they were a scourge on the health of the nation because of their hereditary illnesses, and they needed to be segregated and ultimately erased. This 
position eventually led to the formulation of the theory of negative eugenics as a solution to urban poverty and disease. As eugenicist Arnold White writes in 1885, there is "nothing that the nation can do for these men except let them die out by leaving them alone" (qtd. in Stedman Jones 288-89). ${ }^{15}$ Once Angel becomes convinced of Tess's own urban depravity following their disastrous wedding night, he reaches a conclusion similar to White's. Calling Tess an "exhausted seedling," a typical degenerationist turn of phrase, Angel abandons her, presumably to let her and her hereditary line, in White's words, "die out" (232; vol. 2, ch. 35).

The increasingly hostile approach to the urban poor culminated in the abandonment of programs to moralize and rehabilitate this population, hitherto a popular practice within charity organizations: "Through their exposure of the extent of over-crowding, misery, 'vice,' and crime among the poor, [propertied London] put into question the whole stock of assumptions upon which the work of moralizing the casual poor in the 1870s had been based" (Stedman Jones 282). Giving poor urban dwellers up for lost, degenerationists concluded that maintaining a safe distance from the city's contaminating influence was the only viable protection for those outside the slums. As Stedman Jones writes, "In the mid-1880s, the more predominant feeling was not guilt but fear. There was little empathy or even sentimentality in the descriptions of the poor that came out of the growing literature on 'Outcast London'" (285). In this way, Angel in Tess of the D'Urbervilles can be read as Hardy's enactment of the theories of the countryside to emerge from the growing fear of "Outcast London." Through Angel, Hardy displays the consequences of a view of the world that is predicated upon fear of urban contact and hereditary degeneration: the pathologization and subsequent destruction of Tess, a country dweller who, despite her ruralness, is subject to Victorian conceptions of "Outcast London" due to the displacement of environmental concerns onto individual bodies toward the end of the nineteenth century.

While social purity reformers found the city to be of special importance in the definition of their cause and motives, their perspective on modernity is most relevant to Tess and Angel Clare when we consider what it signified for social purists' conception of rural culture. As I suggested above, if city conditions were increasingly biologized and displaced onto the bodies of "degenerate" individuals, then the country served as the touchstone against which this degeneracy could be compared and validated as aberrant. Quoting several well-known social purity activists from the nineteenth century, including Henry Varley, Elizabeth Blackwell, and Samuel Gregory, Egan and Hawkes discuss the city/country dichotomy present in the discourse of social purity:

\footnotetext{
Societal influence was thought to be particularly perilous for children who lived within the confines of the city. The omnipresent danger of a corrupt social order and over abundance of "licentious" individuals produced an atmosphere that parents needed constantly to defend against. Henry Varley in his Private Address to Boys cautioned that society was "honey-combed" with immoral and prurient influences which were particularly dangerous to children. Unlike the strict social norms which governed rural living, modern society imparted "no fixed standard of right or wrong, in relation to sex." American physician and purity reformer Samuel Gregory lamented that the sexual instinct "appears two or three years earlier in the city than in the country; and four years younger, there, than nature ever designed." (448)
}

Idealizations of rural life were certainly nothing new at the end of the nineteenth century, and Angel has clearly internalized some of his rural prejudices from a vast literary tradition 
stretching back to "pastoral life in ancient Greece," which he attempts to talk to Tess about in chapter nineteen (125; vol. 1, ch. 19). But Angel's vision of the country is not strictly limited to the literary idealizations of the pastoral genre. The interesting point to take away from the social purity activists' rhetorical implementation of the rural as a particularly moral space in a time of degenerate modernization is that they, too, seem to have internalized portions of the cultural and literary myth of the idealized countryside, but they have transformed this myth into a reality specifically sexual in nature, positing that what makes the rural more "moral" than the city is that in rural spaces sexual initiation occurs later, chastity is easier to maintain, and people in the countryside, unlike those in the metropolis, are not beset by irresistible sexual desires, unnatural and premature, that mark the biological degeneration of these city dwellers from healthy and normal to sexually perverse and diseased. As Donald Childs notes, "The very pursuit of sexual gratification as an end in itself was taken as a sign of degeneracy" (72). Angel's inability to view the country outside of his rigid conception of sexual control and renunciation becomes apparent when he and Tess are courting each other and the narrator notes that Angel did "not fully [trow] that in the fields and pastures to 'sigh gratis' is by no means deemed waste; love-making being here more often accepted inconsiderately and for its own sweet sake than in the carking anxious homes of the ambitious" (174; vol. 2, ch. 28). To "sigh gratis," or to love for "its own sweet sake" before an official engagement, establishes the character of the countryside as far other from Angel's chaste understanding of it.

A hypothetical result of social purity's form of rural idealism within the movement is represented by Hardy in his treatment of Angel's perception of the country in opposition to the city and the degree of urgency with which he sets out to prove to himself that the country and its inhabitants conform to a particular conception of healthy ruralism. In the episodes leading up to and including Angel and Tess's marriage, through his representation of Angel's conflicted approach to Tess as a country dweller, Hardy figures the concrete results that follow when one adopts a degenerationist worldview. Keeping in mind the role that the city and modernity played both in the social purity movement and in theories of degeneration, Angel's youthful indiscretion, his torrid "eight-and-forty hours' dissipation" in London with a Londoner, occupies a more significant place in the narrative than a simple anecdotal backstory that establishes Angel's status as a hypocrite (225; vol. 2, ch. 34). ${ }^{16}$ What we learn from this detail in Angel's history is that his ability to control his sexual desire is figured principally as a spatial matter. Fearing that urban vice can be contracted through either heredity or immersion in a metropolitan environment, Angel considers an affair he had with a woman in London to be proof that the city must be avoided to combat the widening reach of sexual depravity. The double threat of hereditary and environmental contagion in an urban context is apparent in the degenerationists' designation of the city as a space that was not only aberrantly immoral, but one that also facilitated the transmission of sexual profligacy through birth in an endless cycle among its inhabitants. Egan and Hawkes write that "employing Christian theological tenets of sexual asceticism and contemporary scientific discourses on heredity, purity campaigners produced a highly ambivalent narrative on sexuality" (447). They add, "Employing a rationale of environmental causality, purity discourses conceptualized the etiology of vice as the result of contagion within the life of the child. . . . Girls raised by prostitutes were believed to 'catch' the deviance from their mothers." Such "theories of transmission" posited by the social purists "stressed the need for a space for children apart from the concerns, desires and dangers found in the adult domain of the public sphere" (448). Speculation about the sources of sexual depravity produced a 
theory of both environmental and hereditary contagion. Social purity activists believed that exercising self-control and avoiding the perils of city life were the best ways to manage these risks. In Egan and Hawkes's prostitute example, for instance, the daughters may either develop deviance through imitation or inherit it through blood. Childs points out that in 1895 criminologist and degenerationist R. L. Dugdale claimed that "harlotry may become a hereditary characteristic and be perpetuated without any specially favoring environment to call it into activity" (72). ${ }^{17}$ Dugdale's statement perfectly reflects a state of affairs in which a problem initially associated with the untoward conditions of a city environment, prostitution, is reconstituted in hereditary terms at the end of the century.

Angel's association of vice with urban environments comes to the fore in his description of the risk he ran to his own moral health when he visited London and engaged in a sexual affair with an urban woman. Before the incident in London occurred, Angel tells Tess, "I loved spotlessness, and hated impurity, as I do now" (224; vol. 2, ch. 34). Nevertheless, the perils, temptations, and conditions of the city were too much for him, and in this particular environment he found it all too easy to abandon his principles. Describing his experience as being "tossed about by doubts and difficulties like a cork on the waves," Angel's prized talent for self-control was no match for the "much-older" woman who "entrapped him," and whom forever after Angel associates with urban profligacy. Disgusted with himself for a mistake that, in his mind, the city of London engendered, Angel consequently develops "an unconquerable, and almost unreasonable, aversion to modern town life" (116; vol. 1, ch. 18).

Social purity reformers in the 1880s and 1890s taught young men like Angel Clare that the city's activation of sexual impulses was a thing to be feared and shunned for the sake of society as a whole, and Angel's permanent removal to the countryside signals that, in his imagination, he has lighted on a space that stabilizes the necessarily unstable ethic of chastity that is integral to his identity, because he believes it to be an enduring component of this environment. In the country, he finds that he can resist his sexual impulses with little trouble as long as his faith in the purity of the country is maintained, reinforcing our sense of the association in Angel's mind between the countryside and the possibility of safety, health, and purity in an otherwise unmanageably blighted and degenerating world. Angel's removal to the countryside after his experience in the corrupt city reflects a popular belief among social purists, that "environment could have a negative effect, but if the biological material was sound then the effects might be reversed through transplantation to a new environment" (Richardson, Love 144).

Nothing disturbs Angel more than instances that trigger him to compare Tess to metropolitan women. Angel finds these moments singularly confusing because he has committed himself to a vision of humanity that does not allow for the elision of the two spaces. As Tess vacillates between accepting and rejecting his proposal, Angel says to her,

\footnotetext{
I cannot think why you are so tantalizing. Why do you disappoint me so? You seem like a coquette, upon my life you do - a coquette of the first urban water! They blow hot and blow cold, just as you do; and it is the very last thing to expect to find in a retreat like Talbothays ... And yet ... I know you to be the most honest, spotless creature that ever lived. So how can I suppose you a flirt? (177; vol. 2, ch. 28; Hardy's emphasis)
}

Flirtation is antithetical to his conception of the rural, or a "retreat like Talbothays," because, from his point of view, coquetry "of the first urban water" insidiously seeks to undermine his 
self-control when he is supposed to be protected from such undermining in the countryside, if, that is, social purity's conception of spatial reality holds true. In a moment that rivals Alec D'Urberville's sexual licentiousness, Angel says to Tess, "Now, Miss Flirt, before you go down. . . . It is a fortnight since I spoke, and this won't do any longer. You must tell me what you mean, or I shall have to leave this house. . . For your own safety I must go" (182; vol. 2, ch. 29). ${ }^{18}$ Although this passage is somewhat similar to benign instances in which Angel stops himself from kissing Tess for "tender conscience's sake" - both functioning as illustrations of his chivalrous power to resist temptation - we can see that his association of flirtation with metropolitan women, and his association of both of these with Tess at times when she appears other than his rural conception of her, threatens to collapse his ethic of chastity into an ethic of sexual license. If Angel's commitment to chastity is brittle at best when Tess's "flirtatious" behavior throws the integrity of the rural into question, his latent licentiousness manifests itself even more dramatically after Tess reveals her past and he has to face "the terrible and total change that her confession had wrought in his life, in his universe" (230; vol. 2, ch. 35). When Angel tells Tess that she must stop appearing flirtatious "for [her] own safety," when he whispers "the most heterodox ideas he could think of" to Mercy Chant, and when he nearly enters into an illicit relationship with Izz Huett, telling her, "you are not to trust me in morals now," what Hardy shows us is that Angel's ethic of chastity conceals a decidedly unchaste sexual propensity that, associated with the city, rises to the surface whenever his faith in Tess's rural purity falters $(267,270$; vol. 3, ch. 40).

\section{The Aristocracy and the City Versus the Unsophisticated Country}

ALLUSIONS TO ANGEL'S HATRED of the London metropolis are so sparse in the novel that reading a corresponding fear of urban degeneracy into his disdain for the city and its sexual depravity may seem like a leap; however, empirical evidence of London's sexual depravity is not Angel's only means of rationalizing his idealization of the health of the rural. Hardy also creates a web of associations between the aristocracy of the past (represented by Tess's D'Urberville ancestors), the aristocracy of the present (represented by Alec D'Urberville's family), and the contemporary city. Angel's fear of hereditary degeneration is primarily figured through his conviction that the D'Urbervilles are the originators of the same sexual depravity that now manifests itself in their rural descendant. Michael Millgate explains that the "Norman-sounding D'Urberville . . . also manages to suggest the urban origins of the nouveau riche family by whom the name has been appropriated" (294). By virtue of its association with the city, the D'Urberville ancestry is also linked to signs of urban sexual depravity on many occasions.

In the late nineteenth century, syphilis was the epidemic of naval towns and cities and the disease that provided the main impetus for the passage of the Contagious Diseases Acts. The Acts applied to garrison towns with high populations of transient military personnel and prostitutes, but the government intended to expand them to include London, igniting among women's reform groups furious controversy that led ultimately to the repeal of the Acts in 1886. ${ }^{19}$ Hardy gestures to the urban associations of syphilis through an itinerant evangelical man who devotes himself to frightening people away from sexual profligacy in both cities and rural areas. He says to Tess of the biblical warnings he blazons on rocks and fences, "You should read my hottest ones - them I kips for slums and seaports" (80; vol. 1, ch. 12). "Slums and seaports" very specifically refers to the areas that were most strongly associated 
with venereal disease and the Contagious Diseases Acts, and the evangelical exhibits the common Victorian attitude toward these areas: they are sites of sexual depravity that require special attention if the spread of disease is to be stopped. In Tess, Hardy systematically equates the sexual depravity of Alec D'Urberville's family (Alec's mother develops blindness from the syphilis she contracted from Simon Stoke D'Urberville) with the sexual depravity of the ancient D'Urbervilles (166; vol. 2, ch. 26). Additionally, because of Alec's oblique association with syphilis and the Contagious Diseases Acts, the two iterations of aristocratic depravity, ancient and modern, are also linked to urban degeneration, though the ancient D'Urbervilles may have lived in mansions situated on "estates" rather than in a modern city.

The associative links between the aristocracy, biological degeneracy (signified through sexual depravity), and the city developed as a result of the alarmist rhetoric of degenerationists and social purity activists at the end of the nineteenth century. It was not only urban dwellers in the slums of London whom degenerationists pathologized, but also aristocratic individuals, these two groups occupying the extreme outer poles on a social continuum at the midpoint of which stood the middle class. In addition to targeting poor urban dwellers, social purity activists, a primarily middle-class group, believed that "the inheritance of wealth, combined with the rule of primogeniture, operated in a dysgenic way, protecting the old aristocracy from the laws of natural selection" (Richardson, Love 151). Angel's ultimate disdain for the D'Urberville ancestry reflects precisely the same tenets touted by social purity. According to the narrator, after Tess and Angel's rupture,

[Angel] was embittered by the conviction that all this desolation had been brought about by the accident of her being a D'Urberville. When he found that Tess came of that exhausted ancient line, and was not of the new tribes from below, as he had fondly dreamed, why had he not stoically abandoned her, in fidelity to his principles? (260; vol. 2, ch. 39)

Angel's contempt for "material distinctions of rank and wealth" stems from his conviction that wealth creates the conditions through which the aristocracy inevitably becomes biologically "exhausted" or degenerate, much like disease becomes self-perpetuating in city slums within social purity rhetoric (116; vol. 1, ch. 18).

Throughout Tess, the urban is equated with the aristocratic, and both of these are identifiable by virtue of their difference from the rural, unworldly, or "unsophisticat[ed]" qualities attributed to Tess and her environment (203; vol. 2, ch. 32). Describing the urban consumers of country milk, Dairyman Crick says to a dairymaid, "Upon my soul, if the London folk only knowed of thee and thy slovenly ways, they'd swaller their milk and butter more mincing than they do a'ready; and that's saying a good deal" (131; vol. 1, ch. 20). Similarly, when Tess quits her job at the dairy to get married, the dairy workers wonder "who would make the ornamental butter-pats for the Anglebury and Sandbourne ladies," Sandbourne being a fashionable "city of detached mansions" newly "spr[u]ng up" (202; vol. 2, ch. 32 and 376; vol. 3, ch. 55). The "mincing habits" of fashionable Londoners and the market for "ornamental butter pats" in Sandbourne link the city to the aristocracy. Likewise, Tess associates London with "noble men and noble women," and Angel somewhat unconsciously shares this perspective, divining in the portraits of the aristocratic D'Urbervilles "women of middle age" and of "merciless treachery," in continuity with the woman "much older than himself" who "nearly entrapped him" in London (216-17; vol. 2, ch. 34 and 116; vol. 1, 
ch. 18). When Tess receives her wedding clothes from London, her immediate reaction upon trying them on is to imagine herself as a member of the medieval aristocracy: "Suppose this robe should betray her by changing colour, as her robe had betrayed Queen Guenever" (206; vol. 2, ch. 32). The allusion to Queen Guenever's adultery and the symbolic connection between a medieval aristocratic robe and a fashionable London wedding dress crystallize the association between the ancient aristocracy, the modern aristocracy, the city, and sexual depravity in the novel.

Angel's anxious response to what he sees as the powerfully negative qualities of the city causes him to look at the country as his saving grace - a place in which he can successfully live out the ethic of chastity and validate his chosen course of existence. On the brink of marrying Tess, Angel remembers that "he had entertained no notion, when doomed as he had thought to an unintellectual bucolic life, that such charms as he beheld in this idyllic creature would be found behind the scenes. Unsophistication was a thing to talk of; but he had not known how it really struck one until he came here" (203; vol. 2, ch. 32). "Unsophistication" in the novel is a euphemism for rural purity, and Angel conceives of it as the reward he is guaranteed by marrying Tess instead of a worldly woman with "social standing" (meaning aristocratic, non-rural, and potentially depraved). He rebukes Tess after she confesses: "I thought ... that by giving up all ambition to win a wife with social standing, with fortune, with knowledge of the world, I should secure rustic unsophistication as surely as I should secure pink cheeks" (237-38; vol. 2, ch. 36). Angel's devotion to this vision of the "unsophisticated" and pure rural in contradiction to the aristocratic and depraved city plays a part in determining his complex reaction to his knowledge of Tess's aristocratic lineage.

The D'Urberville ancestry is dually significant for Angel because of its historical and aristocratic associations, and the manner in which his attitude toward it mutates after Tess confesses her fall stems from the tenets of social purity and sexual determinism that were current at the time of the novel's publication. Shirley A. Martin analyzes Angel's interest in Tess's D'Urberville ancestry in terms of degeneration when she writes that "not only the phenomenon of 'degeneracy,' but the fascination exercised by it, can be read as psychopathology." She suggests that Angel's eventual obsession with the D'Urbervilles, his "rational if excessive contempt for "old families," betrays his own mind's diseased state and can be "put down to ... neurosis." I believe that the significance of Angel's excessive "fascination" for Tess's aristocratic lineage extends beyond this potential reflection of his own psychopathology. Instead, the D'Urberville history mainly reveals the consequences of degeneration theory and its intersecting narratives of urban and aristocratic hereditary pathology.

While Martin and other critics examine the aristocratic associations of the D'Urbervilles, their association with urbanization has received less attention. It would be inaccurate to say that Tess's feudal lineage represents "modernity" in any strict sense of the word since the D'Urbervilles' medieval reign and the perils of late nineteenth-century urbanization could hardly be further apart temporally and categorically, and yet the double metropolitan roots of the name, urbs and ville, suggest that this linkage is not far from Hardy's mind or, more to the point, Angel's mind. After the pivotal scene in the Chase where Alec rapes Tess, the narrator mentions the sexual licentiousness of the medieval D'Urbervilles and uses it to explain Tess's experiences in terms of karmic retribution (74; vol. 1, ch. 11). But while for the narrator Tess suffers the equivalent of what her ancestors dealt to others (rape for rape), for Angel Tess embodies the licentious quality of the D'Urbervilles itself: after her confession, 
Tess is unchaste because her ancestors were unchaste in another epoch of urban decadence that corresponds to his experience of the contemporary city. The combination here of not only urban decadence, but inherited urban decadence, indicates that Angel perceives sexual licentiousness to be a biologically transmitted trait that is associated with urban (or worldly, Angel's euphemism for non-rural and depraved) contact, no matter how far removed this contact is in history from one's current existence. Early in their relationship, when Angel first learns of Tess's ancestry, he says to her, "I should have been glad to know you to be descended exclusively from the long-suffering, dumb, unrecorded rank and file of the English nation, and not from the self-seeking few who made themselves powerful at the expense of the rest" (189; vol. 2, ch. 30). Angel reveals his lack of sympathetic insight with his ignorance of Tess's poverty and the reality of her subjugated social position, misreading her absurdly through heredity as having more direct kinship with her rich and powerful ancestors than with the "long-suffering" and destitute masses.

Angel's idea of heredity plays a more direct role in his rejection of Tess than readers typically realize. When Angel enters the scene at Talbothays Dairy, his position on aristocratic ancestry is apparently deeply ingrained in him and has been for some time. He garners a certain amount of notoriety for his opinion on this subject, and Dairyman Crick and the dairy employees consider his viewpoints to be common knowledge. Crick tells Tess that on one occasion Angel learned of a dairymaid's aristocratic lineage and "spoke quite scornful to the poor girl for days. 'Ah!' he says to her, 'you'll never make a good dairymaid! All your skill was used up ages ago in Palestine, and you must lie fallow for a thousand years to git strength for more deeds!"' (127; vol. 1, ch. 19). Based on this evidence, Tess is rightfully frightened that Angel will reject her if she reveals her own aristocratic ancestry to him. His response to the news during their courtship, however, is unexpectedly favorable, and he even becomes more enthusiastic about it as time passes, hiring their honeymoon rooms at an ancient D'Urberville estate, eagerly planning how he will use this "grand card" to impress his parents with his new bride (210; vol. 2, ch. 33). "I am extremely interested in this news - you can have no idea how interested I am," he says to Tess, and it is evident that Angel himself does not know how interested he is in Tess's aristocratic history, or what particular reasons inform his interest (188; vol. 2, ch. 30). He believes he values her ancestry because it will make her more socially acceptable to his family, but the dramatic change from disgust to enthusiasm, and then back to disgust, that he undergoes during his relationship with Tess indicates that social legitimacy is not all that her lineage conceptually offers him (the superficial status value of the name does not go away with her confession, after all, though his ardor for it does). His statement about the unnamed dairymaid, who must "lie fallow for a thousand years to git strength for new deeds," reveals the significance that the D'Urbervilles ultimately hold for him. Angel's love for Tess and his belief in her absolute purity enable him to come to the conclusion that her family has "lain fallow" long enough for it to have broken its association with urban decadence. In her pure state, Tess acts as a representation of the renewable quality of human nature and proves that the perils of degeneration can be overcome through restitution in the countryside. As a social purist nervous about the power of the city to corrupt and the transmission of promiscuity through both hereditary and environmental forces, he is enthused by the possibility of the sexual redemption of society represented in the pure Tess. After her confession, however, when, in spite of all appearances Tess turns out to have perpetuated her ancestors' legacy (strengthening Angel's sense of environmental and biological determinism), Tess's function as the source of Angel's hope for the future of 
civilization vanishes, largely as a result of concepts he has absorbed from social purity and hereditary determinism.

Angel's zealous interest in the D'Urberville background when he still believes Tess to be pure cannot withstand the news of her rape or seduction by Alec. When Tess reveals her past, he is quick to blame her impurity on her ancestral lineage and, more importantly, on its concomitant urban degeneracy. After she confesses, he says to her,

I cannot help associating your decline as a family with this other fact - of your want of firmness. Decrepit families postulate decrepit wills, decrepit conduct. Heaven, why did you give me a handle for despising you more by informing me of your descent! Here was I thinking you a new-sprung child of nature; there were you, the exhausted seedling of an effete aristocracy! (232; vol. 2, ch. 35)

Angel's reference to her "decrepit will" and "want of firmness" indicates that he now associates her lack of an ethic of chastity with the hereditary transmission of promiscuity and, more specifically, environmentally determined degenerate ("effete") character traits. On the verge of returning to his sleeping wife after he has heard her confession, Angel notices the portrait of one of Tess's female D'Urberville ancestors: "Sinister design lurked in the woman's features, a concentrated purpose of revenge on the other sex - so it seemed to him then. The Caroline bodice of the portrait was low - precisely as Tess's had been when he tucked it in to show the necklace; and again he experienced the distressing sensation of a resemblance between them" (235; vol. 2, ch. 35). The "sinister design" and, earlier, the "merciless treachery" (217; vol. 2 , ch. 34$)$ that he observes in the female faces of these paintings remind him of the woman who "nearly entrapped" him in London, or metropolitan debauchery in general, and the appearance of flirtation that he once considered an inexplicable feature of the pure Tess now, unfortunately, makes all too perfect sense to him. As one of the primary arguments that the social purity activists used to emphasize the necessity for vigilant self-control, the fragility of chastity and its vulnerability to hereditary and environmental forces frighten Angel away from a woman, as he was earlier frightened away from the city, whose essential ability to monitor vigilantly her own sexual impulses has now been called into question.

A wary approach to the effects of hereditary transmission of urban degeneracy is surely one of the reasons Angel is first to bring up the subject of children after Tess's confession. He says to her,

Now I put it to you. Don't think of me or of yourself, my feelings or your feelings. That's not all the difficulty; it lies in another consideration - one bearing upon the future of other people than ourselves. Think of years to come, and children being brought to us, and this past matter getting known - for it must get known. ... Well, think of wretches of our flesh and blood growing up under a taunt which they will gradually get to feel the force of with their expanding years. What an awakening for them! What a prospect! Can you honestly say Remain, after contemplating this contingency? (243; vol. 2, ch. 36)

Ostensibly concerned with the response of other people toward children with a mother of dubious history, Angel's wording here is suggestive. "Growing up under a taunt" could either refer to ridicule, the most apparent reading, or sexual profligacy itself, which, having inherited from their mother, they will "gradually get to feel the force of" along with the sexual 
development of their "expanding years." It seems likely that "a taunt," linked explicitly to "flesh and blood," refers rather more directly to a hereditary affliction, or taint, that for Angel, a degenerationist and incipient eugenicist, is a harbinger of more dire consequences than public scandal. According to Egan and Hawkes, "purity activists believed they could assure a virtuous future if they could guarantee the protection of children," and Angel would have no way of protecting his children - or the strangely collective "future of other people than ourselves" - if they inherit what he perceives to be promiscuous tendencies from their mother and so perpetuate the cycle (447; Hardy 243). To procreate with Tess would have the apocalyptic effect of jeopardizing the health and safety of all futurity through hereditary contamination, perhaps especially because the urban taint is deceptively obscured by her aesthetically convincing rural appearance.

\section{Conclusion}

EARLY IN THE NOVEL TESS frequently rejects the idea of hereditary influence from the ancient D'Urbervilles: "Not a thing that had been theirs did she retain but the old seal and spoon" (102; vol. 1, ch. 16). Empty symbolic objects of a lost aristocratic family, the old seal and spoon and their historical resonances are the only attributes of the D'Urberville family that Tess believes can affect her. However, Hardy does not deny that hereditary influence may play some part in the life of an individual. On more than one occasion the narrator implies that Tess's fate could be the karmic or hereditary outcome of her ancestors' violent and sexual excesses. However, Angel's pathologization of Tess as sexually depraved due to her D'Urberville blood is represented as an extreme subscription to theories of hereditary influence that Hardy is at pains to denounce regardless of his many concessions to heredity in his works.

Hardy questions the extreme pathologizing impulse of degeneration theory through portions of the novel that symbolically connect the rural paradise of the Valley of the Great Dairies to the D'Urbervilles and the city. Though Angel loses faith in rural unsophistication once it has been tainted by urban contact based on the evidence of Tess's lost virginity and "want of firmness," the novel rejects his conclusion by suggesting that the rural environment is made healthier by its figurative commingling with the urban and the aristocratic. Angel seeks a "new-sprung child of nature" in Tess and values her for her "untraditional newness" (232; vol. 2, ch. 35 and 128; vol. 1, ch. 19). He compares her to an inexperienced "wild convolvulus . . that opened itself this morning for the first time" (177; vol. 2, ch. 28). The floral and vegetative language refers to his mania for virginity, of course, but also has the effect of figuring Tess as a plant that grows in rural soil. Angel believes that it is possible for plants and people cultivated in rural environments to be totally free from outside influence, to be "new" and untainted expressly because of their newness.

In contrast to Angel's ideal of rural separation from urban worldliness, Hardy repeatedly imagines the contribution of a mythical city to the very soil of the Valley of the Great Dairies. At the beginning of the novel, we learn that the bones of the ancient D'Urbervilles lie beneath a church located in Kingsbere-sub-Greenhill. John Durbeyfield calls this place "a city," while the boy he is talking to replies, "Tisn't a city . . leastwise 'twasn't when I was there - "twas a little one-eyed, blinking sort o' place" (10; vol. 1, ch. 1). The notion of a lost "city" lying underneath the current countryside ("sub-Greenhill") becomes something of a leitmotif in the novel. Talbothays, in the Valley of the Great Dairies, "stood not remotely from some of the former estates of the D'Urbervilles, near the great family vaults of [Tess's] granddames and 
their powerful husbands," the same site that Durbeyfield ignorantly terms a city, but in reality is a rural village (100; vol. 1, ch. 15). The narrator describes the flat mead of the Valley of the Great Dairies as "a level landscape compounded of old landscapes long forgotten, and, no doubt, differing in character very greatly from the landscape they composed now" (108; vol. 1, ch. 17). The present landscape differs from the old landscapes from which it was "compounded" because the new site is rural while the old had associations of worldly sophistication. One night when Tess and Angel are walking through the countryside in the Valley of the Great Dairies, they stop to listen to the murmur of the streams:

From the whole extent of the invisible vale came a multitudinous intonation; it forced upon their fancy that a great city lay below them, and that the murmur was the vociferation of its populace.

"It seems like tens of thousands of them," said Tess; "holding public meetings in their market-places, arguing, preaching, quarrelling, sobbing, groaning, praying, and cursing." (201; vol. 2, ch. 32)

Not only does the valley conjure impressions of an ancient metropolis populated, as Tess imagines, by "tens of thousands," but its lushness, greenness, beauty, and fertility can be attributed to the effects of this lost city on the current soil. Rivers and streams, as in the above passage, are more than once associated with the valley's worldly aristocratic history. The Var River in the valley "had stolen from the higher tracts and brought in particles to the vale all this horizontal land; and now, exhausted, aged, and attenuated, lay serpentining along through the midst of its former spoils." The current landscape, originally inhabited by worldly aristocrats, flattened out into rural fields due to the action of this "exhausted, aged, and attenuated" river that is described in the same terms of pillage and conquest (spoils, stolen) used to characterize the ancient D'Urbervilles (105; vol. 1, ch. 16). Though the river has degenerated (or exhausted itself - the same word that Angel uses to describe Tess, "the exhausted seedling of an effete aristocracy" [232; vol. 2, ch. 35]), it has made the countryside into the lush environment that Angel treasures. The narrator makes this explicit when he describes the soil that the farmers are shoveling in the valley:

The shovelfuls of loam, black as jet, brought there by the river when it was as wide as the whole valley, were an essence of soils, pounded champaigns of the past, steeped, refined, and subtilized to extraordinary richness, out of which came all the fertility of the mead, and of the cattle grazing there. (193; vol. 2, ch. 31)

Throughout these passages Hardy emphasizes a long process of flattening, of a variegated landscape becoming a level one, of the soils of the past "pounded" into champaigns, or open fields, and the gradual depletion of a powerful river that represents the former power of the D'Urbervilles. Explicitly contradicting Angel's investment in "untraditional newness" and a "new-sprung child of nature," Hardy proposes that the rustic countryside carries traces of worldly sophistication that in the course of time results in lushness, beauty, and health.

Through these images of a historical city underlying or commingling with the countryside, Hardy questions degenerationist ideals of separation in the present day. Hardy is aware of the increased migration to urban areas and alludes to it in Angel's commentary about the country milk transported to London and toward the end of the novel, when the narrator mentions that country tradesmen, "who had formed the backbone of the village in the past, had to seek refuge in the large centers; the process, humorously designated by statisticians 
as 'the tendency of the rural population toward the large towns,' being really the tendency of water to flow uphill when forced by machinery" (352; vol. 3, ch. 51). Overcrowding in cities, the subject of endless commentary by "statisticians" and social scientists at the end of the century, was the source of the same theories of hereditary degeneration that Angel attaches to individuals with urban or worldly associations. In his representation of the Var River and its murmuring streams that intone the "vociferation of [a great city]" within the rural valley, however, Hardy suggests that examining the historical continuity between the ancient aristocracy, the modern aristocracy, and present countryside will also help reveal the interconnectedness of the modern city and the rural, challenging degenerationists' conception of the latter.

Hardy's critique is leveled at the means by which scientific discourses of the late nineteenth century contributed to the ostracism of the more "desperate among mankind," like Tess (301; vol 3, ch. 44). Perpetuating fears about environmental determinism or hereditary transmission of urban degeneracy, according to Hardy, was a counterproductive method that caused the social purity reformers to move beyond their original humanitarian goals and usher in another era of cruelty. It was the belief of the reformers that social purity "might well save the world." Similarly, Angel tells Tess shortly before she confesses that purity "is the only safeguard for us poor human beings" (224; vol. 2, ch. 34). Such apocalyptic visions heighten the already deleterious effects of degenerative theories by discouraging the rehabilitation of city spaces and encouraging hereditary conceptions of urban degeneracy. Resisting degeneration's powerful impulse toward spatial bifurcation and hereditary determinism, Hardy insists that Tess had "[broken] no law known to the environment in which she fancied herself such an anomaly" (86; vol. 1, ch. 13). Through her husband's inability to see Tess as an individual with a "mighty personality" due to his reduction of her to a component of the rural landscape or, later, as a product of her hereditary line, Hardy underscores the inescapable and detrimental effects of degeneration theory on those vulnerable to middle-class prejudice. Early in her relationship with Angel, Tess contemplates "what might have been with me." She says, "My life looks as if it had been wasted for want of chances!" (125-26; vol. 1, ch. 19). Chronicling the victimization of a woman of great potential at the hands of both her society and her degenerationist lover signals Hardy's participation in a particular late-century effort to counter degeneration's growing popularity through representations of the biologization of environmental concerns.

\section{NOTES}

1. Hardy's own agenda when it comes to representing biological determinism and theories of degeneration have been debated, with no clear consensus. Shuttleworth writes of Hardy's "subscription to theories of hereditary transmission of character traits" (136) while Malane claims that Hardy "challenges gender norms that he perceives as 'man-made' but succumbs to or bolsters gender norms that he believes have a biological basis" $(159,189)$. Greenslade argues that as Hardy was forced to revise Tess to make it palatable for the Victorian public, he increasingly relied on the deterministic concept of hereditary degeneration to account for Tess Durbeyfield's fall from virtue (160-62). He concludes that in both Tess and Jude the Obscure, Hardy is unable to extricate himself fully from the ideology of determinism, notwithstanding the fact that he frequently shows characters like Tess, Sue Bridehead, and Jude "struggling to free [themselves] into autonomy and self-awareness" $(159,174)$. Richardson instead 
emphasizes Hardy's resistance to deterministic accounts of human life, claiming that "Thomas Hardy appreciated the close relations between organism and environment and valued the complexities of the natural world. [He] share[s] ground with postgenomic science which emphasises the dynamic relations between world and organism, questioning traditional boundaries, rejecting essentialism" ("Darwin"). Following Richardson's interpretation, I argue that in Tess, through his representation of Angel's adoption of a degenerationist worldview, Hardy displays critical awareness of the dangers and folly of essentialist thought.

2. Unless otherwise noted, all citations for Tess of the D'Urbervilles refer to the Penguin edition, edited by Dolin, 1998.

3. See, for instance, Higgonet's discussion of Tess and her "voice" in "A Woman's Story: Tess and the Problem of Voice," 18-19. Boumelha writes of the "male images and fantasies" directed at Tess, including the "pink cheeks and rustic innocence of Angel's patronizing pastoralism" (125). Lovesey discusses Angel's idealization of Tess in "Reconstructing Tess" and writes, "Angel's passionate idealism ... leads him to naively overvalue superficial signs of purity and wholeness in the world" (915). I would like to suggest further that Angel receives an impetus for his idealizing tendencies from scientific theories of the time, which he uses both to formulate and then to justify his bifurcated view of the world. For Angel, superficial signs of purity and wholeness, such as virginity, become excessively important because of their extrapolated significance within the context of degeneration and eugenics.

4. See Greenslade's chapter "Degenerate spaces" for a discussion of the fixation on urban decay in both fictional and non-fictional writings in the late nineteenth century (47-64). He mentions George Gissing's The Unclassed and Charles Booth's Life and Labour of the People in London as examples of this perspective, and analyzes Hardy's The Mayor of Casterbridge for its representation of the "'urbanising' of rural life," a major concern of degenerationists fearful of the city's power to corrupt $(48-52,54)$.

5. In the 1890s, according to Richardson, "hereditarian discourses were moving away from Darwin, and increasingly underplayed environmental factors, coming to focus on the biology and biological history of the individual" to account for apparent instances of degeneration among humans (Love 202). As "the debates between hereditarians and environmentalists over the role of biology escalated," Richardson points out that "the argument increasingly developed into a circular one, in which bad living conditions were taken as proof of bad heredity" ("Eugenics" 275, 276). Shifting their emphasis from the environment to individual bodies as the self-contained source and locus of degenerative pathologies, observers of urban decay were better able to exonerate themselves of responsibility for the poverty, disease, and social unrest among the lower classes that resulted from industrial upheaval and overcrowding in cities. In Tess, Hardy enacts the process of this pathologization of lower-class individuals.

6. See Hardy, Tess of the D'Urbervilles, 1909. 302.

7. Lovesey similarly situates Tess within the context of the social purity movement and explains how Tess's position as a child-like victim of rape mirrors William T. Stead's journalistic and sensational exposé of child prostitution in "The Maiden Tribute of Modern Babylon," which had the direct effect of raising the age of consent in 1885 (917-25). However, Lovesey does not discuss the later development of the movement toward eugenics or what implications the geographical concerns of the movement have in the novel.

8. Richardson writes, "The idea of rational reproduction has its origins in the social purity movement which developed apace in the $1880 \mathrm{~s}$.... By this time the social purity movement, a loose association of religious and moral crusaders, had become increasingly interventionist, adopting a new, more coercive, policy towards the residuum, and becoming more likely to use the instruments of the state to enforce their moral code" (Love 46).

9. Though Victorians replaced environmental accounts of urban decay with increasingly hereditarian ones, the significance of environment could not be divorced entirely from narratives of degenerative illness due to the strong association between the pathologized "residuum" and their geographic location, the 
city slums of the East End of London (Stedman Jones 283). Even though Victorians were beginning to emphasize hereditary pathology over environmental conditions as the source of urban decay, the continuing influence of an environmental model resulted in a bifurcated vision of environment forwarded by degenerationists and social purity activists. Within this framework, Victorians perceived rural dwellers as healthy and free from contagion and urban dwellers as biological degenerates, circulating disease among themselves within their urban setting.

10. In his history of the social purity movements, Bristow describes how the activism against the Contagious Diseases Acts and the low age of consent for young women reached a peak in July 1885, as social purity activists organized a demonstration to help pass the Criminal Law Amendment Act in Parliament (113). As a burgeoning movement with an increasingly vigorous public following at the time of Tess's inception and composition, this particular manifestation of the mania for social purity, which flares up in different forms periodically throughout history (Bristow discusses instances in Britain from 1700 to the early twentieth century), is likely to have received Hardy's attention. DeVine connects the two when she claims that "in this novel [Hardy] exposes [the] deployment of gendered morality to enforce class identities, not only in fiction, but in the social purity movement generally," although the specific ramifications of the existence of this movement for a character like Angel have yet to be explored (80).

11. Showalter writes that in the late nineteenth century, "the major source of infection, men were told, was the body of the prostitute. The prostitute was the agent of corruption and contamination, whose putrid body bred stench and disease" (193). She adds that syphilis "provided the occasion for sexual and social purity campaigns and for a retreat from the liberalization of sexual attitudes" (188). Syphilis was a "symbolic sexual disease that [took] on apocalyptic dimensions and [was] interpreted as signaling the end of the world" (190).

12. Victorians justified their fear of urban degeneration by citing the supposedly shorter statures and inveterate laziness of city dwellers. For instance, in 1871 the $23^{\text {rd }}$ Annual Report of the Poor Law Board cited "the failure of 15-year-old London boys to reach the required standards of height and girth" and determined that "a stunted growth is characteristic of the race" (Stedman Jones 129).

13. Although I have chosen not to address nineteenth-century race relations or the pathologization of Irish ruralism specifically (which could be mapped onto Tess's experience of oppression), the larger implications of targeting the poor as a massive group in the manner of degenerationists are apparent. Because Tess is the illustrative example here (a lower-class, poor, white rural dweller), it is out of my scope to explore specific racial implications of degenerationist thought since there is less direct evidence that race is a factor in Angel's worldview. However, Stedman Jones's indication that social purists were focused on the health of rural inhabitants in order to prevent the "deterioration of the [white] race" in the cities provides a glimpse of the racist origins of eugenics that would become so pronounced in the beginning of the twentieth century.

14. See, for instance, the frontispiece to Thomas Hobbes's Leviathan, published in 1651. As Olwig explains, Hobbes's image is "a particularly famous example of the depiction of the body politic as an assemblage of bodies within a larger body of a figure representing the state" (87).

15. See White.

16. Angel's widely acknowledged hypocrisy is based on the fact that, though he is not a virgin either before he marries Tess, he abandons her because he finds out that she is not a virgin. This plot point is typically explained as Hardy's comment on the frustrating Victorian double standard that dictates women must be virgins before they are married when the same criterion never applies to men, an assessment that I do not contest, although I believe this moment in the novel has additional layers of complexity.

17. For original passage, see Dugdale 26.

18. Alec D'Urberville justifies his rape of Tess in similar terms, though his capitulation to sexual license does not appear to be spatially determined, as Angel's threatens to be here. Although Alec responds to a religious imperative to attempt to be more pure toward the end of the novel (insisting that Tess is his true wife in the eyes of God), this religious motivation is so different from Angel's entrenchment in degeneration theory that an account of Alec's conversion would require another historical lens of 
evangelical Christianity. Egan and Hawkes explain that "attempting to 'investigate sexual phenomena in an (ideally, if not always actually) dispassionate manner using the tools of rationality,' social purity reformers sought a more scientific, as opposed to a solely religious, approach. Ultimately, it was their hope that 'sex, put under rational guidance, might well save the world"' (446). Angel exhibits the "dispassionate rationality" of the social purists on many occasions, resolving to leave Tess after her confession because he believes his decision "stood on a basis approximating to one of pure reason" (Hardy 250). Alec's Christian conversion, while not central to my argument regarding Hardy's critique of degeneration theory, appears as a counterpart to Angel's similar conversion to social purity. Both result in the oppression of Tess.

19. Walkowitz writes that the "London Metropolitan police eagerly awaited the extension of the Acts to London, where they hoped to institute a system of police de moeurs to supervise and contain the street disorder of West End prostitutes" (23). Following the repeal of the Acts, however, "with regulation and confinement out of the question, London police found themselves increasingly under pressure from social purity and antivice groups to suppress all the indoor resorts of the West End prostitutes . . . as well as clear public thoroughfares and theaters of streetwalkers. ... Crackdowns and ensuing scandals would keep prostitution before the 'public' eye as a confusing and protean identity" (23-24).

\section{WORKS CITED}

Boumelha, Penny. Thomas Hardy and Women: Sexual Ideology and Narrative Form. Totowa: Barnes, 1982. Bristow, Edward J. Vice and Vigilance: Purity Movements in Britain since 1700. New York: Gill, 1977.

Childs, Donald J. Modernism and Eugenics: Woolf, Eliot, Yeats, and the Culture of Degeneration. New York: Cambridge UP, 2001.

DeVine, Christine. Class in Turn-of-the-Century Novels of Gissing, James, Hardy and Wells. Burlington: Ashgate, 2005.

Dugdale, R. L. The Jukes. New York: Putnam's, 1895.

Duncan, Jeffrey L. "The Rural Ideal in Eighteenth-Century Fiction.” Studies in English Literature, 150019008.3 (1968): 517-35.

Egan, R. Danielle and Gail Hawkes. "Producing the Prurient through the Pedagogy of Purity: Child Sexuality and the Social Purity Movement." Journal of Historical Sociology 20.4 (2007): 443-61.

Greenslade, William. Degeneration, Culture, and the Novel, 1880-1940. Cambridge: Cambridge UP, 1994.

Hall, Lesley. "Hauling Down the Double Standard: Feminism, Social Purity, and Sexual Science in Late Nineteenth-Century Britain." Gender \& History 16.1 (2004): 36-56.

Hardy, Thomas. Tess of the D'Urbervilles. New York: Harper, 1909.

Hardy, Thomas. Tess of the D'Urbervilles. Ed. Tim Dolin. New York: Penguin, 1998.

Higgonet, Margaret R. "A Woman's Story: Tess and the Problem of Voice." The Sense of Sex: Feminist Perspectives on Hardy. Ed. Margaret R. Higgonet. Urbana: U of Illinois P, 1993. 14-31.

Hobbes, Thomas. Leviathan: Revised Student Edition. Ed. Richard Tuck. New York: Cambridge UP, 1996.

Kato, Megumi. "The Milk Problem in To the Lighthouse." Virginia Woolf Miscellany 50 (Fall 1997): 5.

Lovesey, Oliver. "Reconstructing Tess." SEL 43.4 (2003): 913-38.

Malane, Rachel. Sex in Mind: The Gendered Brain in Nineteenth Century Literature and Mental Sciences. New York: Peter Lang, 2005.

Martin, Shirley A. "'He knew psychoanalysis': Thomas Hardy and the Paradox of Degeneracy in Tess of the D'Urbervilles." PsyArt: An Online Journal for the Psychological Studies of the Arts. 24 June 2005. N. pag. Web. 23 Sept. 2013.

Millgate, Michael. Thomas Hardy: A Biography. New York: Random, 1982.

Olwig, Kenneth. Landscape, Nature, and the Body Politic. Madison: U of Wisconsin P, 2002.

Pick, Daniel. Faces of Degeneration: A European Disorder, c.1848-c.1918. New York: Cambridge UP, 1989. 
Richardson, Angelique. "Darwin and Reductionisms: Victorian, Neo-Darwinian, and Post-Genomic Biologies." 19: Interdisciplinary Studies in the Long Nineteenth Century 11 (19 Oct. 2010): n. pag. Web. 23 Sept. 2013.

Richardson, Angelique. "Eugenics and Freedom at the Fin de Siècle." Culture and Science in the NineteenthCentury Media. Ed. Louise Henson, Geoffrey Cantor, et al. Burlington: Ashgate, 2004. 275-86.

Richardson, Angelique. Love and Eugenics in the Late Nineteenth Century: Rational Reproduction and the New Woman. New York: Oxford UP, 2003.

Showalter, Elaine. Gender and Culture at the Fin de Siècle. New York: Viking, 1990.

Shuttleworth, Sally. "'Done because we are too menny': Little Father Time and Child Suicide in LateVictorian Culture." Thomas Hardy: Texts and Contexts. Ed. Phillip Mallett. New York: Palgrave, 2002. 133-55.

Stedman Jones, Gareth. Outcast London: A Study in the Relationship between Classes in Victorian Society. Oxford: Clarendon, 1971.

Walkowitz, Judith R. City of Dreadful Delight: Narratives of Sexual Danger in Late Victorian London. London: Virago, 1992.

White, Arnold. “The Nomad Poor of London.” Contemporary Review xlvii (May 1885): 715. 